DOI: https://doi.org/10.31073/abg.59.09

\title{
DURABILITY AND EFFICIENCY OF LIFETIME USE OF RED-AND-WHITE DAIRY CATTLE
}

\author{
Yu. P. POLUPAN ${ }^{1}$, Yu. F. MELNIK ${ }^{1}$, O. D. BIRIUKOVA ${ }^{1}$, M. M. PEREDRIY ${ }^{2}$ \\ ${ }^{1}$ Institute of animal breeding and genetics nd. a. M.V.Zubets of NAAS (Chubynske, Ukraine) \\ ${ }^{2}$ State enterprise of the experimental farm "Khristinovske" (Khristinovka, Ukraine) \\ https://orcid.org/0000-0001-7609-2739-Yu. P. Polupan \\ https://orcid.org/0000-0003-0888-662X-O. D. Biriukova \\ yupolupan@ukr.net
}

The study was conducted on 325 cows of Ukrainian Red-and-White Dairy and Holstein breeds of the herd of the farm "Khristinovske". These cows were descended from 28 bulls of 12 lines and related groups. A sufficiently high level of indicators of the duration and effectiveness of lifetime use of cows was established. The average life expectancy of the cows under control was 2750, economic use was 1711, and lactation was 1459 days. An average of $26221 \mathrm{~kg}$ of milk, $1097 \mathrm{~kg}$ of milk fat and $889 \mathrm{~kg}$ of protein were obtained from cows in lifetime (3.63 lactations).

On average, $8.7 \mathrm{~kg}$ was milked per day of life from cows, on day of economic use - $14.6 \mathrm{~kg}$, on day of lactation $-17.2 \mathrm{~kg}$. Received 657, 1030 and $122 \mathrm{~g}$ of milk fat and protein, respectively. On average, the coefficient of economic use rate was $58.5 \%$, the lactation rate was $85.6 \%$, and productive use was 49.9\%. For most of the studied features of the duration and effectiveness of lifetime use, multidirectional and low interspecific differentiation were established. Holstein cows had the same cows of Ukrainian Red-and-White Dairy breeds as expectancy of life, economic use, and lactation. Cows of the Holstein breed were dominated by cows of Ukrainian Red-and-White Dairy for milk fat and protein yield for one day of life, economic use, lactation and lactation rate. In animals of Ukrainian Red-and-White Dairy breed with increasing conditional bloodiness by Holstein, duration and effectiveness of lifetime use varied curvilinearly. For the most part, the cows group with $87.5 \%$ conditional bloodiness by Holstein had the advantage. A certain level of intergroup differentiation is established by the genetic factors of cows' lineage or related group and father parentage. For the most signes of duration and effectiveness of lifetime use are characterized by the better indicators animals of the P.F. A. Chief 1427381 related group and the genealogical line of R. Citation 267150, and by the worse indicators - P. Astronaut 1458744 line. In some cases, the intergroup difference reaches a significant level (up to $P<0.05$ ). Of the half-sisters by parent groups, the daughters of Tumpi 112367468, Vize 660013269, and Roman 660886883 had the highest prevalence and effectiveness of lifetime use, and the worst were the descendants of Y. J. Gladiator 5840283 and Voron 3206. A dispersion analysis confirmed the genetic predisposition of the phenotypic variability of the studied traits of the duration and effectiveness of economic use of cows. On average, by all counted signs, linear membership determines $6.0 \%$ of the total phenotypic variability, and parentage from father $-12.1 \%$. Therefore, when selecting the sires, their linear identity should be taken into account with the unconditional priority of the breeding value of the bulls according to the complex breeding index.

Keywords: Ukrainian Red-and-White Dairy breed, Holstein breed, duration of economic use, lifetime productivity 


\title{
ТРИВАЛІСТЬ ТА ЕФЕКТИВНІСТЬ ДОВІЧНОГО ВИКОРИСТАННЯ ЧЕРВОНО- РЯБОї МОЛОЧНОЇ ХУДОБИ
}

\author{
Ю. П. Полупан ${ }^{1}$ Ю. Ф. Мельник ${ }^{1}$ О. Д. Бірюкова ${ }^{1}$, М. М. Передрій ${ }^{2}$
}

${ }^{1}$ Інститут розведення і генетики тварин імені М.В.Зубия НААН (Чубинське, Украӥна)

${ }^{2}$ Державне підприємство дослідне господарство «Христинівське» (Христинівка, Україна)

Дослідження проведено на 325 коровах української червоно-рябої молочної та голитинської порід стада племзаводу “Христинівське”, що походили від 28 бугаїв 12 ліній та споріднених груп. Встановлено достатньо високий рівень показників тривалості та ефективності довічного використання корів. Середня тривалість життя підконтрольних корів становила 2750, господарського використання - 1711, лактування - 1459 днів. За життя за 3,63 лактаиій від корів одержсано, у середньому, 26221 кг молока, 1097 кг молочного жиру і 889 кг білка.

На один день життя від корів, у середньому, надоєно 8,7 кг, на день господарського використання - 14,6 кг, лактування - 17,2 кг і одержано відповідно 657, 1030 та 1221 г молочного жиру і білка. У середньому коефіиієнт господарського використання становив 58,5\%, коефіиієнт лактування - 85,6\% і продуктивного використання - 49,9\%. За більшістю досліджуваних ознак тривалості та ефективності довічного використання встановлена різноспрямована і невисока міжсорідна диферениіація. За практично однакової тривалості життя, господарського використання і лактування корови голштинської породи переважали аналогів української червоно-рябої молочної за надоєм і виходом молочного жиру та білка на один день життя, господарського використання, лактування і коефіиієнтом лактування. У тварин украӥнської червоно-рябої молочної породи зі зростанням умовної кровності за поліпшувальною голитинською, тривалість та ефективність довічного використання змінювались криволінійно з перевагою за більшістю ознак групи з кровністю 87,5\%. Певний рівень міжсрупової диференціамії встановлено за генетичними чинниками належності корів до лінії чи спорідненої групи та походження за батьком. За більшістю ознак тривалості та ефективності довічного використання кращими показниками характеризуються тварини спорідненої групи Чіфа 1427381 і генеалогічної лінії Розейф Сайтейшна 267150, гіршими - лінії Астронавта 1458744. В окремих випадках міжгрупова різниия сягала значущого рівня (до $P<0,05)$. 3 груп напівсестер за батьком перевагу за більшістю досліджуваних ознак тривалості та ефеективності довічного використання мали дочки Тумпі 112367468, Віще 660013269 і Романа 660886883, а гіриими виявились потомки Г. Дж. Гладіатора 5840283 і Ворона 3206. Дисперсійним аналізом підтверджено певну генетичну зумовленість фенотипової мінливості досліджуваних ознак тривалості та ефективності господарського використання корів. У середньому, за усіма врахованими ознаками лінійна належність зумовлює 6,0\% загальної фенотипової мінливості, а походження за батьком - 12,1\%. Отже, при підборі плідників слід зважати на їхню лінійну належність за безумовного пріоритету племінної цінності бугаїв за комплексним селекційним індексом.

Ключові слова: українська червоно-ряба молочна порода, голштинська порода, тривалість господарського використання, довічна продуктивність

\section{ПРОДОЛЖИТЕЛЬНОСТЬ И ЭФФЕКТИВНОСТЬ ПОЖИЗНЕННОГО ИСПОЛЬЗОВА- НИЯ КРАСНО-ПЁСТРОГО МОЛОЧНОГО СКОТА}

Ю. П. Полупан ${ }^{1}$, Ю. Ф. Мельник ${ }^{1}$, О. Д. Бирюкова ${ }^{1}$, Н. Н. Передрий ${ }^{2}$

${ }^{1}$ Институт разведения и генетики животных имени М.В.Зубиа НААН (Чубинское, Украина)

${ }^{2}$ Государственное предприятие опьтное хозяйство «Христиновское» (Христиновка, Украина)

Исследования проводились на 325 коровах украинской красно-пёстрой молочной и голштинской пород стада племзавода “Христиновское”, которые были дочками 28 быков 12 линий и родственных групп. Установлен достаточно высокий уровень показателей продолжительности и эффективности пожизненного использования коров. Средняя продолжительность жизни подконтрольных коров составила 2750, хозяйственного использования - 
1711, лактирования - 1459 дней. На протяжении жизни за 3,63 лактаций от коров получено, в среднем, 26221 кг молока, 1097 кг молочного жира и 889 кг белка.

На один день жизни от коров, в среднем, надоено 8, 7 к2, на день хозяйственного использования - 14,6 к2, лактирования - 17,2 кг и получено, соответственно, 657, 1030 и 1221 г молочного жира и белка. В среднем коэффициент хозяйственного использования составил $58,5 \%$, коэффициент лактирования - 85,6\% и продуктивного использования - 49,9\%. По больиинству исследованных признаков продолжительности и эффрективности пожизненного использования установлена разнонаправленная и невысокая межпородная дифференциация. При практически одинаковой продолжсительности жизни, хозяйственного использования и лактирования коровы голитинской породы превосходили аналогов украинской красно-пёстрой молочной по надою и выходу молочного жира и белка на один день жизни, хозяйственного использования, лактирования и коэффициенту лактирования. У животных украинской красно-пёстрой молочной породы при возрастании условной кровности по улучшающей голштинской продолжстельность и эффективность пожизненного использования изменялась криволинейно с преобладанием по большинству признаков группы с кровностью 87,5\%. Определенный уровень межгрупповой дифференциачии установлен по генетическим факторам принадлежности коров к линии или родственной группе и происхождению по отиу. По большинству признаков продолжительности и эффективности пожизненного использования лучшими показателями характеризуются животные родственной группы Чифа 1427381 и генеалогической линии Розейф Сайтейшна 267150, худшими - линии Астронавта 1458744. B отдельных случаях межгрупповая разница достигает значимого уровня (до $P<0,05)$. Из группь полусестёр по отиу преимущество по больиинству исследуемых признаков продолжительности и эффективности пожизненного использования имели дочки Тумпи 112367468, Вище 660013269 и Романа 660886883, а худшими оказались потомки Г. Дж. Гладиатора 5840283 и Ворона 3206. Дисперсионным анализом подтверждено определенную генетическую обусловленность фенотипической изменчивости исследуемых признаков продолжсительности и эффективности хозяйственного использования коров. В среднем, по всем учтённым признакам линейная принадлежность обуславливает 6,0\% общей фенотипической изменчивости, а происхождение по отиу - 12,1\%. Таким образом, при подборе производителей необходимо учитывать их линейную принадлежность при безусловном приоритете племенной иеенности быков согласно комплексному селекционному индексу.

Ключевые слова: украинская красно-пёстрая молочная порода, голштинская порода, продолжительность хозяйственного использования, пожизненная продуктивность

Introduction. The duration of economic use and the lifetime productivity of dairy cows determines the economic efficiency of the industry as a whole. The economic feasibility of keeping a cow is determined by the quantity and quality of produce and the litter. At the same time the indicator of payment of feed with production becomes of great importance. There is a known link between the duration of economic use and the production of more milk and litter [11]. The decrease in the number of calving leads to a reduction in the period of economic use, which directly influences the profitability of milk production [32]. At the same time, the increase in the intensity of breeding in the population and the expanded reproduction of the herd necessitates the search for an economic compromise between genetic improvement and longevity of dairy cattle [30]. It was established [27], that the economic component of the duration of economic use of cows depends more on the endurance of the cow's organism than on the increase in breeding pressure in the herd.

The duration of economic use varies depending on the breed and the direction of the animal's productivity [21]. It is established that animals of high-performance lines are less to the index of productive longevity [5]. Productive longevity of cows depends on paratype factors [19, 23], in particular, the characteristics of rearing young animals $[6,7,20]$, and on genotypic factors (influence of breed, lineage, father) $[7,8,10,16-19,22,25,31]$. The possibility of breeding dairy cows by duration of economic use is a prerequisite for the inclusion of this feature in the structure of breeding indices in countries with intensive management of the industry $[1,13,24]$. 
The purpose of the study is to research the duration and effectiveness of lifetime use of dairy cows of different breeding groups (breed, conditional blood, line, father).

Materials and methods of research. The study was conducted on the basis of primary records in the Ukrainian Red-and-White Dairy breed herd of the State enterprise of the experimental farm "Khristinovske" of the Institute of Animal Breeding and Genetics nd. a. M.V.Zubets of National Academy of Agrarian Sciences of Ukraine. Based on the materials of the electronic information database as of February 7, 2020, using the interface developed by us (O. O. Bokov, Yu. P. Polupan), an observation matrix in the format "*.sta" was formed, which contains data on 451 variables sign of 1927 cows.

A retrospective analysis of the duration and effectiveness of lifetime use of cows was performed according to our proposed method [12-15]. The analysis included information on the economic use and lifetime productivity of 325 cows, the first calving of which dates from 2008-2011 (more than eight years before the retrospective analysis). To compare the group averages of the 12 line and related groups used, only four were focused, with at least three sires daughters involved, and 28 over half-sisters with eight over 15 cows.

In controlled animals the duration (days) of life $\left(\mathrm{T}_{\mathrm{lf}}\right)$, economic use $\left(\mathrm{T}_{\mathrm{eu}}\right)$ and lactation $\left(\mathrm{T}_{\mathrm{lt}}\right)$, number of lactations and live calves for life, lifetime milk yield $(\mathrm{kg})$, content $(\%)$ and yield $(\mathrm{kg})$ of fat and protein, yield of milk $(\mathrm{kg})$, fat and protein $(\mathrm{g})$ for one day of life, economic use and lactation were taken into account or determined. For the periods considered, the coefficients (\%) of economic use $\left(\mathrm{K}_{\mathrm{eu}}[4,28]\right)$, lactation $\left(\mathrm{K}_{\mathrm{lt}}\right)$ and productive use $\left(\mathrm{K}_{\mathrm{pu}}\right)$ were calculated by the formulas [12-15]:

$$
K_{e u}=\frac{T_{e u}}{T_{l f}} \times 100 \% \quad K_{l t}=\frac{T_{l t}}{T_{e u}} \times 100 \% \quad K_{p u}=\frac{T_{l t}}{T_{l f}} \times 100 \% .
$$

The calculations were performed by the methods of mathematical statistics by means of the software package "STATISTICA-12,0" on the PC [3]. The influence of the genetic factors studied was calculated by one-way ANOVA as a ratio of factorial and total variance [9].

Research results. The overall analysis of the all controlled animals shows a sufficiently high level of indicators of duration and effectiveness of lifetime use of the cows of study herd (table 1). Thus, the average life expectancy of cows for 275-802 days exceeded that of the leading breeding herds of the Cherkassy region [2] and for the 586-793 days of controlled Holstein cows, which quitted in 1992-2013 [29]. In terms of duration of economic use, the benefits were 105-656 and 344-557 days, respectively. The lifetime milk yield cows of the studied herd were dominated by the abandoned animals of the leading breeding herds of Cherkassy region by $7021-15628 \mathrm{~kg}$ and exceeded the number of Holstein cows abandoned during 1992-2004 in the Netherlands. The highest lifetime milk yield for the Dutch Holstein cows at $30777 \mathrm{~kg}$ was quitted in 2008 with the disposal [29]. This milk yield is only $17.4 \%$ higher than had cows which quitted at the farm "Khristinovske". The average duration of economic use of controlled cows exceeded 3.6 lactations. The lifetime yield of milk fat and protein from the cows of the study herd were answered by the Holstein cows, which quitted the Netherlands in 2003. The coefficient of productive use testifies that the milking days of cows under control of the studied herd occurred almost every second day of their life.

The analysis of coefficients of variation of the studied signs of lifetime use revealed a higher level of variability compared to individual lactations. Relative indicators of economic, productive use and lactation coefficients show relatively lower variability of the studied traits, and the highest is the proportion of rather rare cases of abortion and birth of dead calves. For most signs of duration and effectiveness of lifetime use of cows of the farm "Khristinovske", the asymmetry and kurtosis rates in the module did not exceed 1, which testified to the close to normal distribution of variational series and possibility of application for analysis of parametric statistics methods. Significant deviation from normal distribution (right asymmetry and positive excess) was found in the frequency of abortions and stillbirths calves, which is characteristic of the distribution of rare Poisson events [9]. A significant left-hand asymmetry and positive excess were noted in lactation coefficient (table 1).

During the last decades, the herd of farm "Khristinovske" has been directing breeding work 
aimed at improving the qualitative composition of the livestock and increasing the genetic potential of animal productivity. To this end, a scientifically sound selection sires for cows is being implemented. During the study period, in the herd used mainly Holstein sires based on the open population principle. This led to an increase in conditional blood for the improving Holstein breed on average to $87.7 \%$ with the formation of a group of 83 conditionally pure Holstein (Red-and-White) cows from crossbreeding.

1. The duration and effectiveness of lifetime use of cows

\begin{tabular}{|c|c|c|c|c|c|c|c|}
\hline \multicolumn{2}{|c|}{ Trait } & $\mathrm{n}$ & $x \pm$ S.E. & S.D. & C.V. & As \pm S.E. & $\mathrm{Ex} \pm$ S.E. \\
\hline \multirow{3}{*}{$\begin{array}{l}\text { Duration of } \\
\text { period, days: }\end{array}$} & life & 325 & $2750 \pm 48.1$ & 868.0 & 31.6 & $0.48 \pm 0.135$ & $-0.54 \pm 0.270$ \\
\hline & economic use & 325 & $1711 \pm 47.7$ & 859.2 & 50.2 & $0.51 \pm 0.135$ & $-0.57 \pm 0.270$ \\
\hline & lactation & 325 & $1459 \pm 42.5$ & 765.3 & 52.5 & $0.48 \pm 0.135$ & $-0.58 \pm 0.270$ \\
\hline \multirow{4}{*}{ During the life: } & lactations & 325 & $3.63 \pm 0.115$ & 2.072 & 57.0 & $0.59 \pm 0.135$ & $-0.45 \pm 0.270$ \\
\hline & live calves & 325 & $3.50 \pm 0.119$ & 2.142 & 61.2 & $0.66 \pm 0.135$ & $-0.16 \pm 0.270$ \\
\hline & stillborn calves, \% & 325 & $6.79 \pm 0.950$ & 17.118 & 252.2 & $3.37 \pm 0.135$ & $13.15 \pm 0.270$ \\
\hline & abortion, \% & 325 & $0.63 \pm 0.363$ & 6.546 & 1046.3 & $12.66 \pm 0.135$ & $176.3 \pm 0.270$ \\
\hline \multirow{4}{*}{$\begin{array}{l}\text { Lifetime dairy } \\
\text { productivity, } \mathrm{kg} \text { : }\end{array}$} & milk yield & 325 & $26221 \pm 948.4$ & 17098.0 & 65.2 & $0.56 \pm 0.135$ & $-0.62 \pm 0.270$ \\
\hline & fat yield & 289 & $1097 \pm 39.1$ & 665.2 & 60.6 & $0.47 \pm 0.143$ & $-0.65 \pm 0.286$ \\
\hline & protein yield & 251 & $889 \pm 30.0$ & 475.9 & 53.6 & $0.33 \pm 0.154$ & $-0.65 \pm 0.306$ \\
\hline & fat + protein & 251 & $2083 \pm 70.9$ & 1122.7 & 53.9 & $0.30 \pm 0.154$ & $-0.75 \pm 0.306$ \\
\hline \multirow{3}{*}{$\begin{array}{l}\text { Milk yield for one } \\
\text { day, kg: }\end{array}$} & life & 325 & $8.7 \pm 0.21$ & 3.75 & 43.1 & $-0.24 \pm 0.135$ & $-0.90 \pm 0.270$ \\
\hline & economic u & 325 & $14.6 \pm 0.27$ & 4.85 & 33.1 & $-0.60 \pm 0.135$ & $0.02 \pm 0.270$ \\
\hline & lactation & 325 & $17.2 \pm 0.28$ & 5.00 & 29.1 & $-0.84 \pm 0.135$ & $0.35 \pm 0.270$ \\
\hline \multirow{3}{*}{$\begin{array}{l}\text { Milk fat and protein } \\
\text { for one day, g: }\end{array}$} & life & 251 & $657 \pm 15.0$ & 237.7 & 36.2 & $-0.53 \pm 0.154$ & $-0.37 \pm 0.306$ \\
\hline & economic use & 251 & $1030 \pm 18.9$ & 299.3 & 29.0 & $-0.88 \pm 0.154$ & $0.39 \pm 0.306$ \\
\hline & lactation & 251 & $1221 \pm 18.6$ & 294.8 & 24.1 & $-0.95 \pm 0.154$ & $0.95 \pm 0.306$ \\
\hline \multirow{3}{*}{ Coefficients of, \%: } & economic use & 325 & $58.5 \pm 0.76$ & 13.78 & 23.6 & $-0.66 \pm 0.135$ & $0.18 \pm 0.270$ \\
\hline & lactation & 325 & $85.6 \pm 0.80$ & 14.33 & 16.7 & $-2.63 \pm 0.135$ & $7.60 \pm 0.270$ \\
\hline & productive use & 325 & $49.9 \pm 0.76$ & 13.73 & 27.5 & $-0.83 \pm 0.135$ & $0.37 \pm 0.270$ \\
\hline
\end{tabular}

For most of the signs studied, interbreed differentiation turned out to be low and insignificant in different directions (table 2). At the same time, it should be noted that in virtually the same duration life, economic use and lactation of cow of the Holstein breed, analogues of Ukrainian Red-and-White Dairy for one day of life for $0.5 \pm 0.48 \mathrm{~kg}$, for one day of economic use prevailed $-1.7 \pm 0.56 \mathrm{~kg}$ $(\mathrm{P}<0.01)$ and lactation $-1.4 \pm 0.59 \mathrm{~kg}(\mathrm{P}<0.02)$. With the yield of milk fat and protein, this advantage was $47 \pm 31.8 \mathrm{~g}, 97 \pm 39.6 \mathrm{~g}(\mathrm{P}<0.02)$ and $87 \pm 39.4 \mathrm{~g}(\mathrm{P}<0.05)$, respectively. The Holstein animals preference for coefficient lactation was also significant $(3.2 \pm 1.52 \%, \mathrm{P}<0.05)$.

In animals of Ukrainian Red-and-White Dairy breed with increasing conditional bloodiness by Holstein, duration and effectiveness of lifetime use varied curvilinearly. For the most part, the cows group with $87.5 \%$ conditional bloodiness by Holstein had the advantage. In particular, by milk yield one day of life, they were dominated by analogues with lower blood by Holstein of $1.5 \pm 0.54 \mathrm{~kg}$ $(\mathrm{P}<0.01)$ and higher $-2.1 \pm 0.68 \mathrm{~kg}(\mathrm{P}<0.01)$. For one day of lactation - by $2.1 \pm 0.72(\mathrm{P}<0.01)$ and $2.0 \pm 0.88 \mathrm{~kg}(\mathrm{P}<0.05)$, respectively, for economic use - by $2.0 \pm 0.70(\mathrm{P}<0.01)$ and $2.0 \pm 0.88 \mathrm{~kg}(\mathrm{P}<0.05)$.

A certain level of intergroup differentiation was established according to the genetic factor of cows belonging to a line or kindred group (table 3).

In duration life expectancy, the best indicator is the cow O. Ivanhoe 1189870 related group, which exceeded analogues of the P. Astronaut 1458744 line worse than this group by $247 \pm 187.0$ days. In terms of duration of economic use the best related group of P. F. A. Chief 1427381 was dominated by $\mathrm{P}$. Astronaut 1458744 line animals by $332 \pm 183.9$ days $(\mathrm{P}<0.1)$, by duration of lactation - by $263 \pm 167.3$ days, and by lactation over life - by $0.78 \pm 0.496$, by lifetime milk yield - by $6775 \pm 3992.7(\mathrm{P}<0.1)$, by milk yield per day of life - by $1.6 \pm 0.90(\mathrm{P}<0.1)$ by the coefficient economic use - by $6.5 \pm 3.05 \%(\mathrm{P}<0.05)$. P. Astronaut 1458744 line was also the worst in terms of stillbirths. Abortions were recorded only in animals of P. F. A. Chief 1427381 related group. 
2. Duration and efficiency of lifetime use of cows of different breeds and conditional bloodiness $(x \pm$ S.E.)

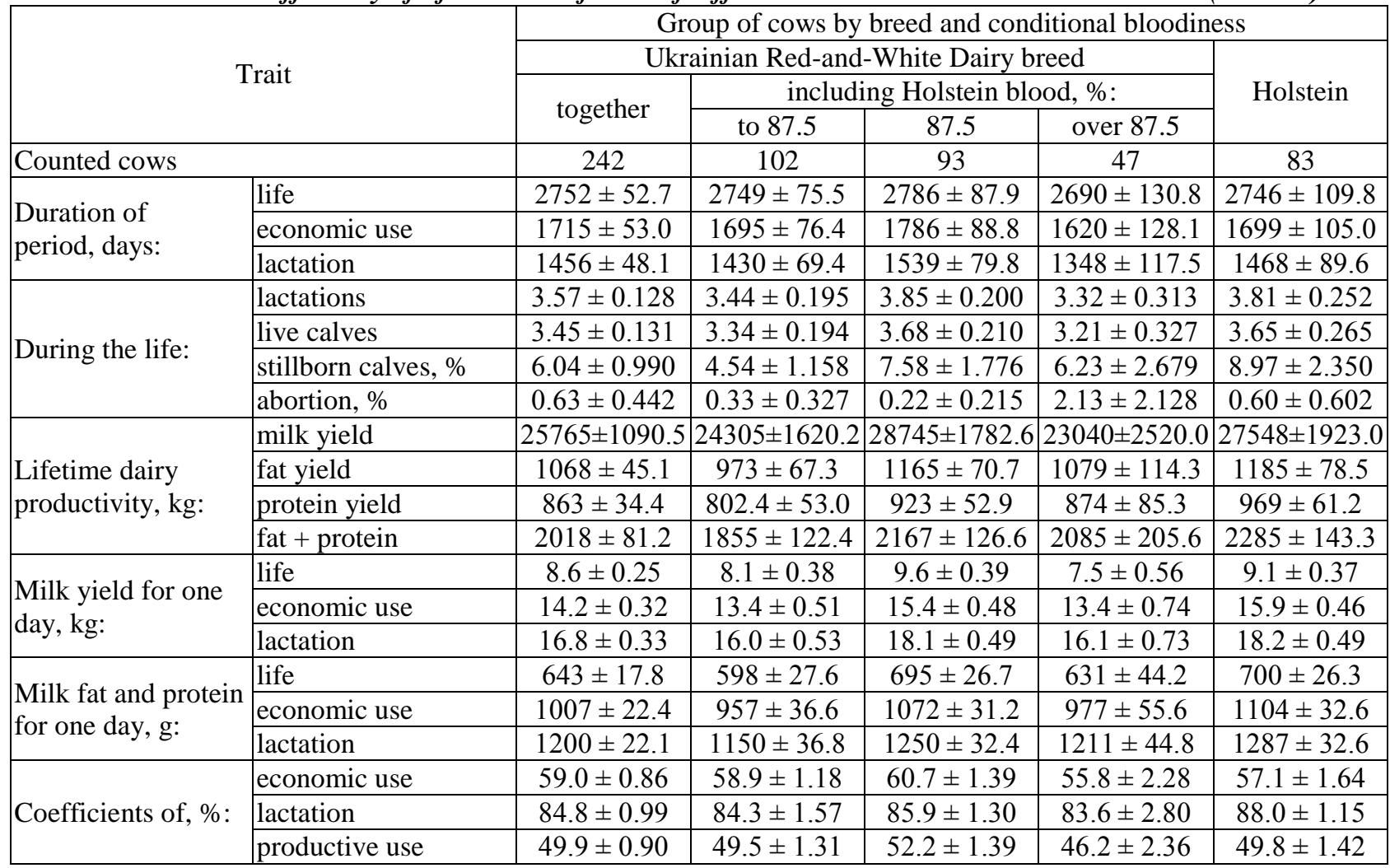

3. Duration and effectiveness of lifetime use of cows of different line and related groups $(x \pm$ S.E.)

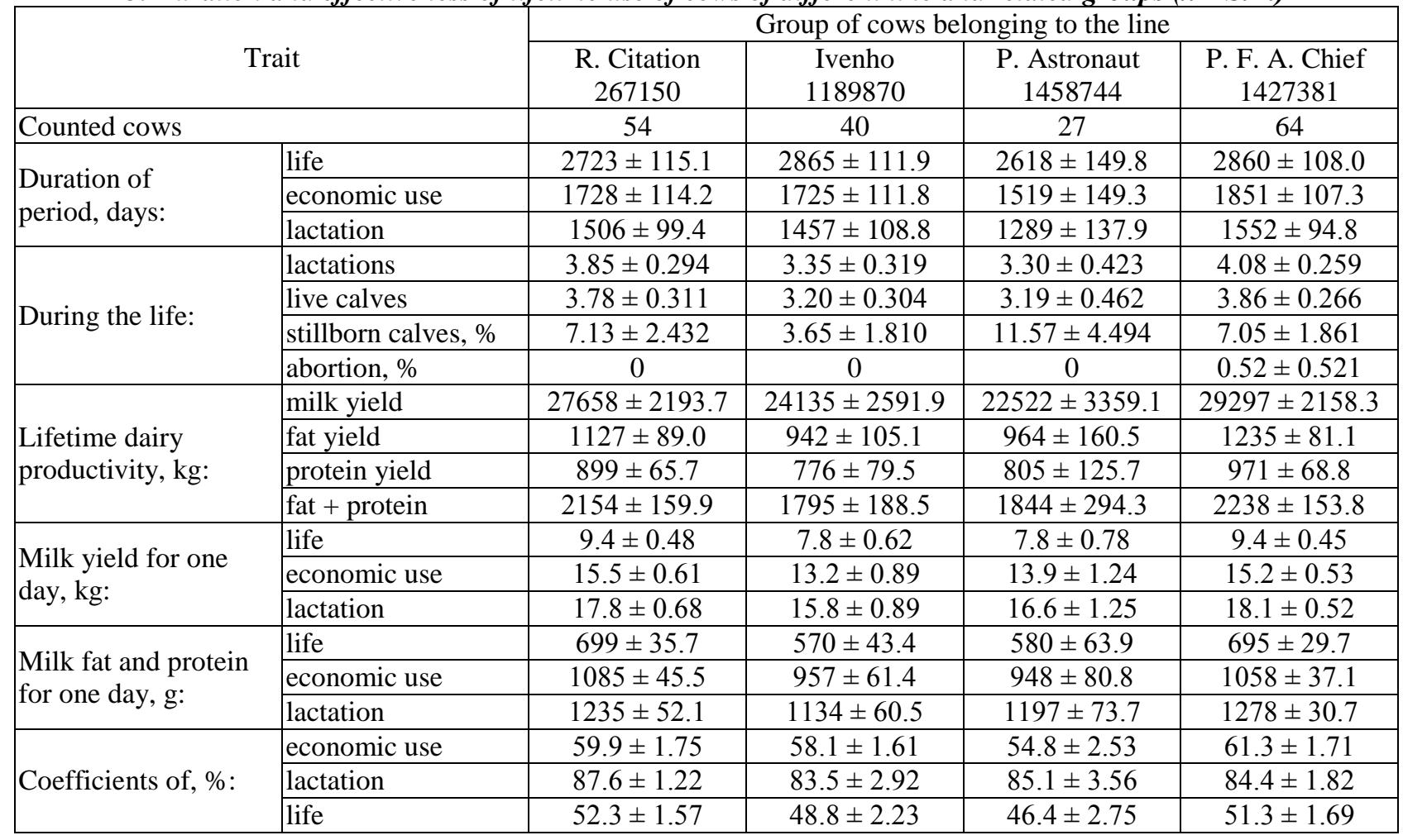

Milk yield for one day of economic use, milk fat and protein yield for one day of life and economic use, and coefficients of lactation and productive use were better the cows of the R. Citation 267150 line. For the most part of the duration and effectiveness of lifetime use, animals of the P. F. A. Chief 1427381 related group and the R. Citation 267150 line are characterized by the best 
indicators, the worst - the Astronaut 1458744 line. In some cases the intergroup difference is significant level.

Of the genetic factors the most significant influence on phenotypic variability of quantitative traits is usually the origin of the father (heritability). Comparison of group averages confirmed a significant level of interspecific differentiation of half-sisters by father (table 4). Among the comparison groups of half-sisters with a herd of more than 15 cows were the daughters of the Voron 3206 (81.3\% conditional blood in Holstein) and Solist 7959 (87.5\% conditional blood in Holstein) and six purebred Holstein sires.

On duration of life the daughters of the sire Tumpi 112367468 exceeded analogues, daughtersof the Solist 7959 by $225 \pm 216.3$ days. On the duration of economic use the daughters of Vize 660013269 had higher indices, than the daughters of H. J. Gladiator 5840283 by $298 \pm 215.5$ days, on the duration of the lactation period - the daughters of Tumpi 112367468 exceededy daughters of H. J. Gladiator 5840283 by $243 \pm 194.9$ days. The largest number of lactations during lifehad the daughters of Tumpi 112367468 with superiority over the half-sisters, daughters of Voron 3206 by $1.27 \pm 0.593$ lactations $(\mathrm{P}<0.05)$. The largest number of stillbirths was recorded amongst, daughters of Roman 660886883, and the lowest - amongst daughters of Vize 660013269. Abortions were recorded only amongst the daughters of Holstein bulls Roman 660886883 and H. J. Gladiator 5840283.

A significant prevalence on lifetime dairy productivity is found for the daughters of Tumpi 112367468. On lifetime milk yield they exceeded the half-sisters of Voron 3206 by $10994 \pm 5078.6 \mathrm{~kg}$, on milk fat yield - by $607 \pm 203.0 \mathrm{~kg}(\mathrm{P}<0.01)$, on milk protein yield - daughters of H. J. Gladiator 5840283 by $431 \pm 131.0 \mathrm{~kg}(\mathrm{P}<0.01)$ and on total milk fat and protein yield by $1016 \pm 310.3 \mathrm{~kg}(\mathrm{P}<0.01)$. The daughters of Tumpi 112367468 also had the highest milk yield per one day of life, economic use and lactation. Their overweight on milk yield per one day of life over the daughters of H. J. Gladiator 5840283 was $3.2 \pm 0.85 \mathrm{~kg}(\mathrm{P}<0.001)$, per one day of economic use $-5.0 \pm 0.90 \mathrm{~kg}(\mathrm{P}<0.001)$ and per one day of lactation by $5.1 \pm 1.05 \mathrm{~kg}(\mathrm{P}<0.001)$. On the milk fat and protein yield per one day of life daughters of Roman 660886883 prevailed over the daughters of H. J. Gladiator 5840283 by $268 \pm 52.1 \mathrm{~g}$ ( $\mathrm{P}<0.001)$, per one day of economic use - by $337 \pm 60.8 \mathrm{~g}(\mathrm{P}<0.001)$. The superiority of the daughters of Tumpi 112367468 over the half-sisters, daughters of H.J. Gladiator 5840283 on milk fat and protein yield per one day of lactation was $338 \pm 68.3 \mathrm{~g}$ with the highest level of significance $(\mathrm{P}<0.001)$.

On coefficients of economic use Frigate 3014630261 daughters had an advantage over cows daughters of H. J. Gladiator 5840283 by $6.5 \pm 3.48 \%$ (P < 0.1 ). On coefficients of lactation the the group of dughters of Diplomat 401497, that was characterized with the highest indices outperformed Frigate 3014630261 daughters by $7.4 \pm 4.95 \%$, and on the productive use coefficient this group indices prevailed Voron 3206 daughters' indices by $4.5 \pm 4.26 \%$ and Solist 7959 daughters' - by $4.3 \pm 3.05 \%$.

Previously, we have found [12] that breeding "in itself" crossbreed animals for reproductive crossing does not significantly reduce the overall efficiency of lifetime use of cows. In the investigated herd of the farm "Khristinovske", the use of bulls of the Ukrainian Red-and-White Dairy breed Voron 3206 and Solist 7959 for purebred breeding for life duration reveals close to average herd values. According to some of investigated signs of effectiveness of lifetime use, this selection shows slightly better results compared to the absorbent crossing with some Holstein sires (in particular, H. J. Gladiator 5840283). 
4. Duration and effectiveness of lifetime use of daughters of different bulls ( $x \pm$ S.E. $)$

\begin{tabular}{|c|c|c|c|c|c|c|c|c|c|}
\hline \multirow{2}{*}{\multicolumn{2}{|c|}{ Trait }} & \multicolumn{8}{|c|}{ A group of half-sisters cows by their father } \\
\hline & & $\begin{array}{l}\text { Voron } \\
3206\end{array}$ & $\begin{array}{l}\text { Solist } \\
7959\end{array}$ & $\begin{array}{c}\text { Vize } \\
660013269 \\
\end{array}$ & \begin{tabular}{|c|} 
Diplomat \\
401497 \\
\end{tabular} & \begin{tabular}{|c|} 
Roman \\
660886883 \\
\end{tabular} & $\begin{array}{c}\text { Tumpi } \\
112367468 \\
\end{array}$ & $\begin{array}{c}\text { Frigate } \\
3014630261 \\
\end{array}$ & $\begin{array}{l}\text { H. J. Gladiator } \\
5840283\end{array}$ \\
\hline Counted cows & & 16 & 25 & 20 & 53 & 57 & 27 & 18 & 30 \\
\hline \multirow{3}{*}{$\begin{array}{l}\text { Duration of } \\
\text { period, days: }\end{array}$} & life & $2740 \pm 163.2$ & $2641 \pm 161.1$ & $3027 \pm 171.0$ & $2711 \pm 116.6$ & $2727 \pm 129.6$ & $2905 \pm 173.8$ & $2766 \pm 198.8$ & $2680 \pm 128.8$ \\
\hline & economic use & $1625 \pm 170.0$ & $1562 \pm 158.4$ & $1858 \pm 167.5$ & $1724 \pm 116.3$ & $1718 \pm 125.1$ & $1844 \pm 175.8$ & $1792 \pm 201.1$ & $1560 \pm 135.6$ \\
\hline & lactation & $1370 \pm 178.9$ & $1346 \pm 142.1$ & $1559 \pm 156.8$ & $1503 \pm 101.3$ & $1474 \pm 106.2$ & $1570 \pm 147.5$ & $1426 \pm 174.1$ & $1327 \pm 127.5$ \\
\hline \multirow{4}{*}{ During the life: } & lactation & $2.88 \pm 0.455$ & $3.44 \pm 0.444$ & $3.85 \pm 0.504$ & $3.83 \pm 0.298$ & $3.72 \pm 0.292$ & $4.15 \pm 0.380$ & $3.67 \pm 0.524$ & $3.10 \pm 0.326$ \\
\hline & live calves & $2.69 \pm 0.395$ & $3.40 \pm 0.473$ & $3.75 \pm 0.497$ & $3.75 \pm 0.316$ & $3.47 \pm 0.305$ & $3.89 \pm 0.382$ & $3.56 \pm 0.550$ & $3.07 \pm 0.328$ \\
\hline & stillborn calves, \% & $5.47 \pm 3.779$ & $6.50 \pm 2.660$ & $1.67 \pm 1.667$ & $7.27 \pm 2.475$ & $8.92 \pm 2.774$ & $8.52 \pm 3.249$ & $5.09 \pm 2.789$ & $5.14 \pm 2.460$ \\
\hline & abortion, $\%$ & $\begin{array}{l}0 \\
\end{array}$ & \begin{tabular}{|l|}
0 \\
\end{tabular} & \begin{tabular}{|l|}
0 \\
\end{tabular} & 0 & $2.11 \pm 1.783$ & 0 & \begin{tabular}{|l|}
0 \\
\end{tabular} & $1.67 \pm 1.667$ \\
\hline \multirow{4}{*}{$\begin{array}{l}\text { Lifetime dairy } \\
\text { productivity, } \mathrm{kg} \text { : }\end{array}$} & milk yield & $19802 \pm 3984.2$ & $23863 \pm 3491.4$ & $28232 \pm 3930.0$ & $27734 \pm 2234.2$ & $27286 \pm 2299.0$ & $30796 \pm 3149.3$ & $25212 \pm 4349.2$ & $19876 \pm 2780.7$ \\
\hline & fat yield & $764 \pm 162.6$ & $1047 \pm 167.1$ & $1094 \pm 154.1$ & $1133 \pm 90.6$ & $1189 \pm 91.8$ & $1371 \pm 121.5$ & $1041 \pm 163.2$ & $783 \pm 116.8$ \\
\hline & protein yield & $715 \pm 142.9$ & $840 \pm 128.2$ & $824 \pm 111.4$ & $905 \pm 67.1$ & $1013 \pm 70.3$ & $1058 \pm 98.1$ & $839 \pm 142.7$ & $627 \pm 86.8$ \\
\hline & fat + protein & $1642 \pm 336.7$ & $1925 \pm 300.1$ & $1918 \pm 264.4$ & $2169 \pm 163.0$ & $2405 \pm 161.2$ & $2473 \pm 226.7$ & $1880 \pm 305.5$ & $1457 \pm 211.9$ \\
\hline \multirow{3}{*}{$\begin{array}{l}\text { Milk yield for one } \\
\text { day, kg: }\end{array}$} & life & $6.7 \pm 1.01$ & $8.2 \pm 0.78$ & $8.6 \pm 0.90$ & $9.5 \pm 0.49$ & $9.1 \pm 0.47$ & $9.9 \pm 0.58$ & $8.3 \pm 0.95$ & $6.7 \pm 0.62$ \\
\hline & economic use & $11.7 \pm 1.55$ & $14.5 \pm 1.25$ & $14.0 \pm 1.19$ & $15.6 \pm 0.62$ & $15.3 \pm 0.60$ & $16.5 \pm 0.57$ & $12.9 \pm 1.18$ & $11.5 \pm 0.70$ \\
\hline & lactation & $14.2 \pm 1.57$ & $16.8 \pm 1.28$ & $16.9 \pm 1.17$ & $17.9 \pm 0.69$ & $17.6 \pm 0.63$ & $19.1 \pm 0.68$ & $16.4 \pm 1.19$ & $14.0 \pm 0.80$ \\
\hline \multirow{3}{*}{$\begin{array}{l}\text { Milk fat and protein } \\
\text { for one day, g: }\end{array}$} & life & $542 \pm 79.0$ & $603 \pm 63.4$ & $584 \pm 60.5$ & $705 \pm 36.1$ & $747 \pm 24.5$ & $741 \pm 36.6$ & $612 \pm 61.6$ & $479 \pm 46.0$ \\
\hline & economic use & $936 \pm 110.8$ & $977 \pm 80.0$ & $951 \pm 80.0$ & $1092 \pm 46.0$ & $1147 \pm 33.2$ & $1140 \pm 34.3$ & $935 \pm 77.0$ & $810 \pm 50.9$ \\
\hline & lactation & $1092 \pm 111.6$ & $1178 \pm 75.8$ & $1151 \pm 77.5$ & $1242 \pm 52.8$ & $1323 \pm 31.7$ & $1339 \pm 38.6$ & $1199 \pm 58.5$ & $1001 \pm 56.3$ \\
\hline \multirow{3}{*}{ Coefficients of, \%: } & economic use & $57.5 \pm 2.52$ & $55.8 \pm 2.64$ & $59.2 \pm 2.30$ & $60.0 \pm 1.78$ & $58.9 \pm 1.86$ & $59.5 \pm 2.77$ & $62.0 \pm 2.69$ & $55.5 \pm 2.21$ \\
\hline & lactation & $83.5 \pm 5.66$ & $87.1 \pm 3.10$ & $82.5 \pm 3.78$ & $87.6 \pm 1.24$ & $87.4 \pm 1.63$ & $86.8 \pm 1.53$ & $80.2 \pm 4.79$ & $83.9 \pm 3.11$ \\
\hline & productive use & $47.9 \pm 3.95$ & $48.1 \pm 2.60$ & $49.4 \pm 3.07$ & $52.4 \pm 1.60$ & $50.9 \pm 1.65$ & $51.0 \pm 2.17$ & $49.2 \pm 3.25$ & $50.0 \pm 2.56$ \\
\hline
\end{tabular}


5. Influence of genetic factors on indicators of duration of economic use of cows

\begin{tabular}{|c|c|c|c|c|c|}
\hline \multirow{3}{*}{\multicolumn{2}{|c|}{ Trait }} & \multicolumn{4}{|c|}{ The influence of the organized factor: } \\
\hline & & \multicolumn{2}{|c|}{ father } & \multicolumn{2}{|c|}{ line, comparison group } \\
\hline & & $\eta_{x}^{2} \pm S . E ., \%$ & $P$ & $\eta_{x}^{2} \pm S . E ., \%$ & $P$ \\
\hline \multirow{2}{*}{$\begin{array}{l}\text { Number of degrees } \\
\text { of freedom: }\end{array}$} & factorial & \multicolumn{2}{|l|}{27} & \multicolumn{2}{|l|}{11} \\
\hline & general & \multicolumn{2}{|l|}{288} & \multicolumn{2}{|c|}{304} \\
\hline \multirow{3}{*}{ Duration period, days: } & life & $8.0 \pm 9.32$ & 0.581 & $2.4 \pm 3.62$ & 0.766 \\
\hline & economic use & $8.0 \pm 9.32$ & 0.578 & $2.7 \pm 3.62$ & 0.664 \\
\hline & lactation & $8.4 \pm 9.31$ & 0.495 & $2.6 \pm 3.62$ & 0.706 \\
\hline \multirow{4}{*}{ During the life: } & lactation & $7.5 \pm 9.32$ & 0.663 & $2.9 \pm 3.62$ & 0.622 \\
\hline & live calves & $7.7 \pm 9.32$ & 0.635 & $2.9 \pm 3.62$ & 0.616 \\
\hline & stillborn calves, $\%$ & $17.9 \pm 9.07$ & $<0.001$ & $3.0 \pm 3.62$ & 0.585 \\
\hline & abortion, \% & $3.5 \pm 9.36$ & 0.998 & $1.6 \pm 3.62$ & 0.932 \\
\hline \multirow{4}{*}{$\begin{array}{l}\text { Lifetime dairy } \\
\text { productivity, kg: }\end{array}$} & milk yield & $9.9 \pm 9.28$ & 0.263 & $4.1 \pm 3.61$ & 0.300 \\
\hline & fat yield & $12.4 \pm 9.54$ & 0.079 & $7.0 \pm 4.02$ & 0.045 \\
\hline & protein yield & $12.3 \pm 10.07$ & 0.129 & $8.3 \pm 4.61$ & 0.035 \\
\hline & fat + protein & $12.9 \pm 10.05$ & 0.092 & $8.9 \pm 4.60$ & 0.021 \\
\hline \multirow{3}{*}{ Milk yield for one day, $\mathrm{kg}$ : } & life & $15.2 \pm 9.16$ & 0.005 & $7.3 \pm 3.60$ & 0.016 \\
\hline & economic use & $16.9 \pm 9.11$ & $<0.001$ & $9.4 \pm 3.59$ & 0.001 \\
\hline & lactation & $13.7 \pm 9.20$ & 0.019 & $8.6 \pm 3.59$ & 0.003 \\
\hline \multirow{3}{*}{$\begin{array}{l}\text { Milk fat and protein for } \\
\text { one day, } g \text { : }\end{array}$} & life & $20.3 \pm 9.80$ & $<0.001$ & $15.9 \pm 4.52$ & $<0.001$ \\
\hline & economic use & $19.9 \pm 9.82$ & $<0.001$ & $14.1 \pm 4.55$ & $<0.001$ \\
\hline & lactation & $17.5 \pm 9.91$ & 0.004 & $13.8 \pm 4.55$ & $<0.001$ \\
\hline \multirow{3}{*}{ Coefficients of, \%: } & economic use & $13.8 \pm 9.20$ & 0.018 & $3.1 \pm 3.62$ & 0.566 \\
\hline & lactation & $7.9 \pm 9.20$ & 0.593 & $1.8 \pm 3.62$ & 0.891 \\
\hline & productive use & $12.7 \pm 9.22$ & 0.042 & $2.8 \pm 3.62$ & 0.647 \\
\hline
\end{tabular}

An analysis of variance confirmed the genetic predisposition of the phenotypic variability of the studied signs of the duration and efficiency of economic use of cows (table 5). On the basis of duration life, economic use, lactation, number of calves and calves received, lifetime dairy productivity, genetic variance was low (2.4-2.9\% by linear affiliation and $7.5-8 \%$ by parental origin) for unreliable level of significance. On the variability of the birth rate of dead calves, influence of father parentage increases to a significant (almost 18\%) reliable level. Abortion rates also have a non-significant and unreliable level of genetic predisposition (1.6-3.5\%). The influence of genetic factors on the variability of lifetime dairy productivity increases to $4.1-8.9 \%$ by linearity and $9.9-12.9 \%$ by father parentage, remaining at an unreliable level of significance. Relatively low $(1.8-3.1 \%$ by linear affiliation and $7.9-13.8 \%$ by father parentage) and in most cases the genetic predisposition of economic and productive use and lactation rates was unreliable.

The final comprehensive criterion for effectiveness of lifetime use of dairy cows is seen to be milk fat and protein yield per day of life, economic use and lactation. On these grounds, a relatively higher and in most cases highly reliable (up to $\mathrm{P}<0.001$ ) level of genetic predisposition was detected. The influence of line or comparison group on these indicators ranged from 7.3 to $15.9 \%$, parentage from the father - from 13.7 to $20.3 \%$. This level of genetic variability gives reason to expect effectiveness of breeding improvements in efficiency of lifetime use of dairy cattle.

Generally, belonging to a line or a comparison group accounted for $6.0 \%$ of the total phenotypic variability for all these traits and $12.1 \%$ for father parentage. That is, impact of father parentage was expected to be [26] twice as high as belonging to a line or related group. Therefore, when selecting the sires, their linear identity should be taken into account with unconditional priority of the breeding value of the bull according to complex breeding index.

Conclusions. For most of the studied traits of duration and effectiveness of lifetime use, multidirectional and low interspecific differentiation were established. With virtually the same duration life, economic use and lactation of the Holstein cow, analogues of Ukrainian Red-and-White Dairy breed for milk fat and protein yield for one day of life, economic use, lactation and lactation factor prevailed. 
In animals of Ukrainian Red-and-White Dairy breed with increasing conditional bloodiness by Holstein, duration and effectiveness of lifetime use varied curvilinearly. For the most part, the cows group with $87.5 \%$ conditional bloodiness by Holstein had the advantage.

A certain level of intergroup differentiation is established by the genetic factors of cows' lineage or related group and father parentage. For the most traits of duration and effectiveness of lifetime use are characterized by the better indicators animals of the P. F. A. Chief 1427381 related group and the genealogical line of R. Citation 267150 and by the worse indicators - P. Astronaut 1458744 line. Of the half-sisters by parent groups, daughters of Tumpi 112367468, Vize 660013269, and Roman 660886883 had the predominance of most investigated signs of duration life and lifetime use, and the worst were descendants of H. J. Gladiator 5840283 and Voron 3206.

An analysis of variance confirmed the genetic predisposition of the phenotypic variability of the studied signs of duration and effectiveness of economic use of cows. On average by all counted traits linear membership determines $6.0 \%$ of the total phenotypic variability, and parentage from father $-12.1 \%$. Therefore, when selecting breeders, their linear identity should be taken into account with the unconditional priority of the breeding value of the bull according to the complex breeding index.

\section{BIBLIOGRAPHY}

1. Басовський, Д. М. Методичні підходи щодо оцінки генетичної цінності бугаїв молочних порід за комплексом ознак у Північній Америці / Д. М. Басовський // Розведення і генетика тварин. - Київ, 2014. - Вип. 48. - С. 18-23.

2. Бащенко, М. І. Продуктивне довголіття корів молочних порід Черкащини / М. І. Бащенко, І. В. Тищенко, К. Г. Малік // Вісник Черкаського інституту агропромислового виробництва. - Черкаси, 2004. - Вип. 4. - С. 9-20.

3. Боровиков, В. П. STATISTICA. Искусство анализа данных на компьютере: для профессионалов / В. П. Боровиков. - Санкт-Петербург : Питер, 2003. - 688 с.

4. Відтворювальна здатність чорно-рябих корів різного походження і генотипів в умовах українського Полісся / М. С. Пелехатий, Н. М. Шипота, 3. О. Волківська, Т. В. Федоренко // Розведення і генетика тварин. - Київ : Аграрна наука, 1999. - Вип. 31-32. - С. 180-182.

5. Каратєєва, О. І. Ефективність тривалості господарського використання корів голштинської породи / О. I. Каратєєва, А. В. Безбабна // Науковий вісник Національного університету біоресурсів і природокористування України. Серія : “Технологія виробництва і переробки продукції тваринництва”. - Київ, 2014. - Вип. 202. - С. 175-178.

6. Комков, Д. Г. Продолжительность и интенсивность использования коров с разным возрастом и живой массой при первом отёле / Д. Г. Комков, Р. М. Кертиев, Н. М. Кертиева // Молочное и мясное скотоводство. - 2019. - № 7. - С. 42-45.

7. Мазур, Н. П. Формування високопродуктивного молочного стада 3 тривалим господарським використанням: науково-методичні рекомендації / Н. П. Мазур, Є. І. Федорович, В. В. Федорович. - Львів : Інститут біології тварин НААН, 2019. - 30 с.

8. Підпала, Т. В. Продуктивне довголіття молочної худоби голштинської породи різної селекції / Т. В. Підпала, Є. М. Зайцев // Вісник аграрної науки Причорномор'я. - Одеса, 2018. Вип. 3. - С. 40-45.

9. Плохинский, Н. А. Биометрия / Н. А. Плохинский. - Москва : Изд-во МГУ, 1970. - 367 с.

10. Полупан, Ю. П. Генетична детермінація тривалості та ефективності довічного використання чорно-рябої молочної худоби / Ю. П. Полупан // Розведення і генетика тварин. - Київ, 2015. - Вип. 49. - С. 120-133.

11. Полупан, Ю. П. Ефективність використання корів залежно від їхнього віку / Ю. П. Полупан, Т. П. Коваль // Вісник аграрної науки. - 2004. - № 2. - С. 29-35.

12. Полупан, Ю. П. Ефективність довічного використання корів: до методики групування $\mathrm{i}$ вплив умовної кровності / Ю. П. Полупан // Розведення і генетика тварин. - Київ, 2014. Вип. 48. - С. 98-113. 
13. Полупан, Ю. П. Ефективність довічного використання корів різних країн селекції / Ю. П. Полупан // Вісник Сумського національного аграрного університету. Серія : “Тваринництво". - 2014. - Вип. 2/2 (25). - С. 14-20.

14. Полупан, Ю. П. Ефективність довічного використання червоної молочної худоби / Ю. П. Полупан // Розведення і генетика тварин. - Київ : Аграрна наука, 2000. - Вип. 33. C. 97-105.

15. Полупан, Ю. П. Методика оцінки селекційної ефективності довічного використання корів молочних порід / Ю. П. Полупан // Методологія наукових досліджень 3 питань селекції, генетики та біотехнології у тваринництві : матеріали науково-теоретичної конференції (Чубинське, 25 лютого 2010 року). - Київ : Аграрна наука, 2010. - С. 93-95.

16. Попов, Н. А. Продолжительность продуктивного использования коров в стаде чёрнопёстрой породы / Н. А. Попов, А. А. Некрасов, Е. Г. Федотова // Зоотехния. - 2019. - № 7. C. 8-12.

17. Тривалість використання та відтворювальна здатність тварин сірої та білоголової українських порід / Н. Л. Рєзникова, Ю. П. Полупан, О.В.Денисюк, Ю. В. Вдовиченко, А. В. Писаренко, Н. М. Фурса // Розведення і генетика тварин. - Київ, 2018. - Вип. 56. C. $162-173$.

18. Хмельничий, Л. М. Мінливість довічної продуктивності корів української чорно-рябої молочної породи залежно від генеалогічних формувань / Л. М. Хмельничий, А. М. Салогуб, А. П. Шевченко // Вісник Сумського національного аграрного університету. Серія : “Тваринництво”. - 2012. - Вип. 10. - С. 12-17.

19. Хмельничий, Л. М. Продуктивне довголіття корів молочної худоби в аспекті впливу генотипових та паратипових чинників / Л. М. Хмельничий, В. В. Вечорка, В. М. Бондарчук // Вісник Сумського національного аграрного університету. Серія : “Тваринництво”. - 2017. Вип. 7 (33). - С. 106-120.

20. Хмельничий, С. Л. Тривалість життя корів української чорно-рябої молочної породи в залежності від рівня оцінки лінійних ознак будови тіла / С. Л. Хмельничий // Вісник Сумського національного аграрного університету. Серія : “Тваринництво”. - 2016. Вип. 5 (29). - С. 98-105.

21. Федорович, В. В. Тривалість господарського використання та причини вибуття корів молочних та комбінованих порід / В. В. Федорович, С. І. Федорович, Н. П. Мазур // Вісник Сумського національного аграрного університету. Серія : “Тваринництво”. - 2019. Вип. 5 (29). - С. 110-114.

22. Analysis of culling records and estimation of genetic parameters for longevity and some production traits in Holstein dairy cattle / M. Ghaderi-Zefrehei, E. Rabbanikhah, H. Baneh, S. O. Peters, I. G. Imumorin // Journal of Applied Animal Research. - 2017. - Vol. 45, no. 1. - P. 524-528. doi:10.1080/09712119.2016.1219258.

23. Associations between strain, herd size, age at first calving, culling reason and life time performance characteristics in Holstein-Friesian cows / K. Adamczyk, J. Makulska, W. Jagusiak, A. Węglarz // Animal. - 2017. - Vol. 11, no. 2. - P. 327-334.

24. Combining genetic and physiological data to identify predictors of lifetime reproductive success and the effect of selection on these predictors on underlying fertility traits / N. A. Dennis, K. Stachowicz, B. Visser, F. S. Hely, D. K. Berg, N. C. Friggens, P. R. Amer, S. Meier, C. R. Burke // J. Dairy Sci. - 2018. - Vol. 101, is. 4. - P. 3176-3192.

25. Dechow, C. D. The effect of sire selection on cow mortality and early lactation culling in adverse and favorable cow survival environments / C. D. Dechow, R. C. Goodling, S. P. Rhode // Prev. Vet. Med. - 2012. - Vol. 103, no. 2-3. - P. 228-233. doi:10.1016/j.prevetmed.2011.09.020.

26. De Mello, F. Longevity in dairy cattle / F. de Mello, E. L. Kern, A. Bretas // J. Adv. Dairy Res. - 2014. - Vol. 2, is. 3. - P. 126-128. doi:10.4172/2329-888X.1000126.

27. De Vries, A. Economic trade-offs between genetic improvement and longevity in dairy cattle / A. De Vries // J. Dairy Sci. - 2017. - Vol. 100, is. 5. - P. 4184-4192. 
28. Dickerson, G. E. Butterfat production, reproduction, growth, and longevity in relation to age at first calving / G. E. Dickerson, A. B. Chapman // J. Anim. Sci. - 1940. - Is. 1. - P. 76-81.

29. Dutch herds increase life time production and long evity. - 2013. - Режим доступу : http://www.crv4all.com/dutch-herds-increase-lifetime-production-and-longevity/

30. Overton, M. W. Symposium review: An abundance of replacement heifers. What is the economic impact of raising more than are needed? / M. W. Overton, K. C. Dhuyvetter // J. Dairy Sci. 2020. - Vol. 103, is. 4. - P. 3828-3837.

31. Predisposing factors for involuntary culling in Holstein-Friesian dairy cows / D. Chiumia, M. G. G. Chagunda, A. I. Macrae, D. J. Roberts // Journal of Dairy Research. - 2013. - Vol. 80, is. 1. - P. 45-50.

32. Relationship between reproduction traits and functional longevity in Canadian dairy cattle / A. Sewalem, F. Miglior, G. J. Kistemaker, P. Sullivan, B. J. Van Doormaal // J. Dairy Sci. - 2008. Vol. 91, is. 4. - P. 1660-1668.

\section{REFERENCES}

1. Basovs'kyy, D. M. 2014. Metodychni pidkhody shchodo otsinky henetychnoyi tsinnosti buhayiv molochnykh porid za kompleksom oznak u Pivnichniy Amerytsi Methodical approaches to assessing the genetic value of dairy breeds in North America. Rozvedennya i henetyka tvaryn - Animal Breeding and Genetics. 48:18-23 (in Ukrainian).

2. Bashchenko, M. I., I. V. Tyshchenko, and K. H. Malik. 2004. Produktyvne dovholittya koriv molochnykh porid Cherkashchyny - Productive longevity of dairy cows of Cherkasy region. Visnyk Cherkas'koho instytutu ahropromyslovoho vyrobnytstva - Bulletin of Cherkasy Institute of Agroindustrial Production. 4:9-20 (in Ukrainian).

3. Borovikov, V. P. 2003. STATISTICA. Iskusstvo analiza dannykh na komp'yutere: dlya professionalov - STATISTICA. Art of analysis of data on a computer: for professionals. SPb : Piter, 688 (in Russian).

4. Pelekhatyy, M. S., $\quad$ N. M. Shypota, Z. O. Volkivs'ka, and T. V. Fedorenko. 1999. Vidtvoryuval'na zdatnist' chorno-ryabykh koriv riznoho pokhodzhennya i henotypiv $\mathrm{v}$ umovakh ukrayins'koho Polissya - Reproductive ability of black-and-white cows of different origins and genotypes in Ukrainian Polissya. Rozvedennya i henetyka tvaryn - Animal Breeding and Genetics. 3132:180-182 (in Ukrainian).

5. Karatyeyeva, O. I., and A. V. Bezbabna. 2014. Efektyvnist' tryvalosti hospodars'koho vykorystannya koriv holshtyns'koyi porody - Efficiency of duration of economic use of Holstein cows. Naukovyy visnyk NUBiP. Seriya «Tekhnolohiya vyrobnytstva i pererobky produktsiyi tvarynnytstva»-Scientific Bulletin NUB\&P. Series "Technology of production and processing of livestock products". 202:175-178 (in Ukrainian).

6. Komkov, D. G., R. M. Kertiev, and N. M. Kertieva. 2019. Prodolzhitel'nost' i intensivnost' ispol'zovaniya korov s raznym vozrastom i zhivoy massoy pri pervom otele - Duration and intensity of use of cows with different ages and live weight at the first calving. Molochnoe i myasnoe skotovodstvo - Dairy and beef cattle. 7:42-45 (in Russian).

7. Mazur, N. P., Ye. I. Fedorovych, and V. V. Fedorovych. 2019. Formuvannya vysokoproduktyvnoho molochnoho stada z tryvalym hospo-dars'kym vykorystannyam: Naukovometodychni rekomendatsiyi - Formation of high-performance dairy herd with long economic use: Scientific and methodological recommendations. L'viv, Instytut biolohiyi tvaryn NAAN, 30 (in Ukrainian).

8. Pidpala, T. V., and Ye. M. Zaytsev. 2018. Produktyvne dovholittya molochnoyi khudoby holshtyns'koyi porody riznoyi selektsiyi - Productive longevity of dairy cattle of Holstein breed of different breeding. Visnyk ahrarnoyi nauky Prychornomor"ya - Bulletin of agrarian science of the Black Sea region. 3:40-45 (in Ukrainian).

9. Plokhynskyy, N. A. 1970. Byometryya - Biometry. Moskva, Yzd-vo MHU, 367 (in Russian). 
10. Polupan, Yu. P. 2015. Henetychna determinatsiya tryvalosti ta efektyvnosti dovichnoho vykorystannya chorno-ryaboyi molochnoyi khudoby - Genetic determination of the duration and effectiveness of lifetime use of black-and-white dairy cattle. Rozvedennya i henetyka tvaryn - Animal Breeding and Genetics. 49:120-133 (in Ukrainian).

11. Polupan, Yu. P., and T. P. Koval' 2004. Efektyvnist' vykorystannya koriv zalezhno vid yikhn'oho viku - Effectiveness of use of cows depending on their age. Visnyk ahrarnoyi nauky - Bulletin of agrarian science. 2:29-35 (in Ukrainian).

12. Polupan, Yu. P. 2014. Efektyvnist' dovichnoho vykorystannya koriv: do metodyky hrupuvannya i vplyv umovnoyi krovnosti - The efficiency of lifetime use of cows: to the grouping method and the influence of conditional blood. Rozvedennya i henetyka tvaryn - Animal Breeding and Genetics. 48:98-113 (in Ukrainian).

13. Polupan, Yu. P. 2014. Efektyvnist' dovichnoho vykorystannya koriv riznykh krayin selektsiyi - Efficiency of lifetime use of cows from different breeding countries. Visnyk Sums'koho natsional'noho ahrarnoho universytetu. Seriya "Tvarynnytstvo" - Bulletin of Sumy National Agrarian University. Series "Livestock". 25:14-20 (in Ukrainian).

14. Polupan, Yu. P. 2000. Efektyvnist' dovichnoho vykorystannya chervonoyi molochnoyi khudoby - The effectiveness of lifetime use of red dairy cattle. Rozvedennya i henetyka tvaryn Animal Breeding and Genetics. 33:97-105 (in Ukrainian).

15. Polupan, Yu. P. 2010. Metodyka otsinky selektsiynoyi efektyvnosti dovichnoho vykorystannya koriv molochnykh porid - Methods of estimation of breeding efficiency of lifetime use of dairy cows. Metodolohiya naukovykh doslidzhen' z pytan' selektsiyi, henetyky ta biotekhnolohiyi u tvarynnytstvi : materialy naukovo-teoretychnoyi konferentsiyi - Research methodology for breeding, genetics and biotechnology in animal husbandry: Proceedings of a scientific-theoretical conference. 93-95 (in Ukrainian).

16. Popov, N. A., A. A. Nekrasov, and E. G. Fedotova. 2019. Prodolzhitel'nost' produktivnogo ispol'zovaniya korov v stade cherno-pestroy porody - Duration of productive use of cows in a herd of Black-and-White breed. Zootekhniya - Animal Science. 7:8-12 (in Russian).

17. Ryeznykova, N. L., Yu. P. Polupan, O. V. Denysyuk, Yu. V. Vdovychenko, A. V. Pysarenko, and N. M. Fursa. 2018. Tryvalist' vykorystannya ta vidtvoryuval'na zdatnist' tvaryn siroyi ta biloholovoyi ukrayins'kykh porid - Duration of use and reproductive capacity of animals of gray and white-headed Ukrainian breeds. Rozvedennya i henetyka tvaryn - Animal Breeding and Genetics. 56:162-173 (in Ukrainian).

18. Khmel'nychyy, L. M., A. M. Salohub, and A. P. Shevchenko. 2012. Minlyvist' dovichnoyi produktyvnosti koriv ukrayins'koyi chorno-ryaboyi molochnoyi porody zalezhno vid henealohichnykh formuvan' - Variability of lifetime productivity of cows of Ukrainian Black-andWhite Dairy breed depending on genealogical formations. Visnyk Sums'koho natsional'noho ahrarnoho universytetu. Seriya "Tvarynnytstvo" - Bulletin of Sumy National Agrarian University. Series "Livestock". 10:12-17 (in Ukrainian).

19. Khmel'nychyy, L. M., V. V. Vechorka, and V. M. Bondarchuk. 2017. Produktyvne dovholittya koriv molochnoyi khudoby v aspekti vplyvu henotypovykh ta paratypovykh chynnykiv - Productive longevity of dairy cows in the aspect of influence of genotypic and paratypic factors. Visnyk Sums'koho natsional'noho ahrarnoho universytetu. Seriya "Tvarynnytstvo" - Bulletin of Sumy National Agrarian University. Series "Livestock". 7(33):106-120 (in Ukrainian).

20. Khmel'nychyy, S. L. 2016. Tryvalist' zhyttya koriv ukrayins'koyi chorno-ryaboyi molochnoyi porody $\mathrm{v}$ zalezhnosti vid rivnya otsinky liniynykh oznak budovy tila - Life expectancy of cows of Ukrainian Black-and-White Dairy breed depending on the level of assessment of linear features of body conformation. Visnyk Sums'koho natsional'noho ahrarnoho universytetu. Seriya "Tvarynnytstvo" - Bulletin of Sumy National Agrarian University. Series "Livestock". 5(29):98-105 (in Ukrainian).

21. Fedorovych, V. V., Ye. I. Fedorovych, and N. P. Mazur. 2019. Tryvalist' hospodars'koho vy- 
korystannya ta prychyny vybuttya koriv molochnykh ta kombinovanykh pored - Duration of economic use and reasons for disposal of cows of dairy and mixed breeds. Visnyk Sums'koho natsional'noho ahrarnoho universytetu. Seriya "Tvarynnytstvo" - Bulletin of Sumy National Agrarian University. Series "Livestock" 5(29):110-114 (in Ukrainian).

22. Ghaderi-Zefrehei, M., E. Rabbanikhah, H. Baneh, S. O. Peters, and I. G. Imumorin. 2017. Analyses of culling records and estimation of genetic parameters for longevity and some production traits in Holstein dairy cattle. Journal of applied animal research. 45(1):524-528. Doi:10.1080/09712119.2016.1219258 (in English).

23. Adamczyk, K., J. Makulska, W. Jagusiak, and A. Węglarz. 2017. Associations between strain, herd size, age at first calving, culling reason and lifetime performance characteristics in HolsteinFriesian cows. Animal. 11(2):327-334 (in English).

24. Dennis, N. A., K. Stachowicz, B. Visser, F. S. Hely, D. K. Berg, N. C. Friggens, P. R. Amer, S. Meier, and C. R. Burke. 2018. Combining genetic and physiological data to identify predictors of lifetime reproductive success and the effect of selection on these predictors on underlying fertility traits. J. Dairy Sci. 101, is. 4:3176-3192 (in English).

25. Dechow, C. D., R. C. Goodling, and S. P. Rhode. 2012. The effect of sire selection on cow mortality and early lactation culling in adverse and favorable cow survival environments. Prev. Vet. Med. 103(2-3):228-233. Doi:10.1016/j.prevetmed.2011.09.020. (in English).

26. De Mello, F., E L. Kern, A. Bretas. 2014. Longevity in Dairy Cattle. J. Adv. Dairy Res. 2(3):126-128. Doi:10.4172/2329-888X.1000126 (in English).

27. De Vries, A. 2017. Economic Trade-offs Between Genetic Improvement and Longeviny in Dairy Cattle. J. Dairy Sci. 100(5):4184-4192 (in English).

28. Dickerson, G. E., and A. B. Chapman. 1940. Chapman Butterfat production, reproduction, growth, and longevity in relation to age at first calving. J. Anim. Sci. 1:76-81 (in English).

29. Dutch herds increase lifetime production and longevity. 2013. Rezhym dostupu: http://www.crv4all.com/dutch-herds-increase-lifetime-production-and-longevity/ (in English).

30. Overton, M. W., and K. C. Dhuyvetter. 2020. Symposium review: An abundance of replacement heifers. What is the economic impact of raising more than are needed? Journal Dairy Science. Apr. 103(4):3828-3837. Doi: 10.3168/jds.2019-17143 (in English).

31. Chiumia, D., M. G. G. Chagunda, A. I. Macrae, and D. J. Roberts. 2013. Predisposing factors for involuntary culling in Holstein-Friesian dairy cows. Journal of dairy research. 80(1):45-50 (in English).

32. Sewalem, A., F. Miglior, G. J. Kistemaker, P. Sullivan, and B. J. Van Doormaal. 2008. Relationship between reproduction traits and functional longevity in Canadian dairy cattle. J. Dairy Sci. 91:1660-1668 (in English).

Одержано редколегією 21.04.2020 p.

Прийнято до друку 30.04.2020 p. 